\title{
VOCABULARY KNOWLEDGE LEARNING AND READING COMPREHENSION PERFORMANCE: WHICH ONE IS SUPERIOR - BREADTH OR DEPTH?
}

\author{
SEYEd MOHAMMAD MOHAMMADI \& NASROLlaH BAYAT AFSHAR ${ }^{1}$ \\ Kharazmi University of Tehran (Iran)
}

\section{RESUMEN}

La lectura ha sido y es una tarea demandada para los aprendices de segundas lenguas. Igualmente, el aprendizaje de vocabulario juega un papel vital en el aprendizaje de una lengua extranjera y numerosos investigadores han establecido la correlación entre conocimiento del vocabulario y la comprensión lectora. Sin embargo, la investigación sobre la amplitud y la profundidad en el conocimiento del vocabulario de aprendices de inglés como lengua extranjera (EFL - English as a Foreign Language) y sus interacciones mutuas es inadecuada. De manera similar, este artículo intenta revisar las relaciones entre el conocimiento del vocabulario de alumnado EFL y su comprensión lectora, así como analizar si la amplitud y la profundidad de dicho conocimiento de vocabulario están correlacionadas. Habiendo revisado numerosos estudios al respecto, encontramos que al tiempo que la profundidad y la amplitud en el conocimiento del vocabulario tienen papeles esenciales en la comprensión lectora de los aprendices EFL, la profundidad juega un papel más esencial, si cabe. También encontramos que la profundidad y la amplitud en el conocimiento del vocabulario están correlacionadas de manera positiva, es decir, aquel alumnado que mostraba un amplio conocimiento en el número de palabras, también mostraba un conocimiento más profundo de esas palabras.

Palabras clave: Actuación lectora, profundidad léxica, amplitud léxica.

\section{ABSTRACT}

Reading has been and is a demanding task for foreign language learners. Correspondingly, vocabulary knowledge plays an extremely vital role in foreign language learning and numerous researchers have investigated the correlation between vocabulary knowledge and reading comprehension. However, research on breadth and depth of EFL learners' vocabulary knowledge and their mutual interactions is inadequate. Accordingly, the present paper intends to review the relationships between EFL students' vocabulary knowledge and reading comprehension and analyze whether breadth and depth of vocabulary knowledge are correlated to each other. Having reviewed numerous studies in this regard, it was found that whereas both breadth and depth vocabulary knowledge have vital roles in EFL learners' reading comprehension performance, depth of vocabulary knowledge plays a more significant role. It was also found that depth and breadth of vocabulary knowledge are positively correlated, that is, those learners who had large vocabulary size will have a deeper knowledge of the words, too.

Key words: Reading performance, depth of vocabulary knowledge, breadth of vocabulary knowledge.

\section{Introduction}

Reading can be regarded as one of the most central skills in any language because it is a source of information and pleasure as well as a means of strengthening knowledge of the language (Rashidi and Khosravi, 2010).

\footnotetext{
1 Emails: mado.enaj@yahoo.com ; nasr.afshar35@gmail.com
} 
As Schellings, Aarnoutse, and Leeuwe (2006) assert, 'Reading is the construction of the meaning of text. It is an active and strategic process, in which the reader's skill and knowledge interact with the characteristics of the text such as genre, the wording and structure of the text' (p.550).

Laufer (1997) emphasizes that background knowledge, the knowledge of vocabulary in a text, and the application of general reading strategies have dramatic effects on reading comprehension. Nonetheless, vocabulary knowledge has been considered as the most influential component of reading. As such, it is necessary to spend several lines to illuminate the nature of vocabulary knowledge a bit clearer.

\subsection{Defining vocabulary knowledge through frameworks}

In recent decades, second language (L2) vocabulary researchers have offered different but complementary frameworks in order to provide a comprehensive definition about vocabulary knowledge (Richards, 1976; Chappelle , 1998; Henriksen, 1999).

Richards (1976) documented seven aspects of vocabulary knowledge (e.g. associations, syntactic, semantic value, underlying form, behavior and derivations and different meanings). Nation (1990) made a distinction between eight types of vocabulary knowledge (e.g., function, meaning, form, grammatical pattern and relation with other words).

Chapelle (1998) asserted that any feature definition of vocabulary must enclose the four dimensions: (a) knowledge of word characteristics, (b) size of vocabulary, (c) processes of lexical access and (d) organization of lexicon.

Nation (1990) proposed eight facets of vocabulary knowledge: (1) the written form of the word, (2) the spoken form of a word, (3) the associations the word has with other related words, (4) the stylistic register constraints of the word, (5) the frequency of the word, (6) the collocation behavior of the word, (7) the conceptual meaning of the word, and (8) the grammatical behavior of the word. Other researchers have suggested different aspects of vocabulary knowledge (Henriksen, 1999; Schmitt, N. \& Meara, 1997).

Qian's (2002) recent framework consists of earlier-mentioned dimensions of: (a) vocabulary size, (b) automaticity of receptive-productive knowledge, (c) lexical organization, and (d) depth of vocabulary knowledge.

\subsection{Vocabulary Knowledge and Reading Comprehension}

Vocabulary knowledge plays a very important function in the process of language learning. Many researchers have confirmed the very vital role of vocabulary on learners' reading comprehension (Anderson \& Freebody, 1983; Mezynski, 1983; Nation, 1990; Read, 1989, 1993; Qian, 1998, 1999, 2002).

As Stahl $(1983$, p.33) suggests, "One of the best documented relationships in reading research" is the relationship between reading comprehension and vocabulary knowledge. This relationship has been the main incentive for numerous researchers to consider the reader's vocabulary knowledge as the top predictor of his/her understanding of text (Anderson \& Freebody, 1981).

Knowing the meanings of words and their different collocations is in direct connection with reading comprehension and thus vocabulary signifies a significant element to increasing reading achievement (Beck, Perfetti, and McKeown, 1982).

Nation (1990) declares that interest in the association between and reading comprehension and vocabulary has a very lengthy history in the research of ESL/EFL reading. Numerous researchers suppose that vocabulary learning is the very most chief feature of second-language learning (Knight, 1994; Schmitt, 2008). Richek (2005) asserts that reading attainment can be best predicted by vocabulary knowledge.

Bromley (2004) states that vocabulary knowledge sponsors reading fluency, enhances academic achievement and improves reading comprehension. "It is clear that a large and rich vocabulary is the hallmark of an individual. Indeed, a large vocabulary repertoire facilitates becoming an educated person to 
the extent that vocabulary knowledge is strongly related to reading proficiency in particular and school achievement in general" (Beck, McKeown, and Kucan, 2002, p.1).

Several authors have stressed on the crucial role of vocabulary knowledge on reading comprehension in their studies (Hu and Nation, 2000; Hirsh and Nation, 1992). Nassaji (2004) accepts it as true that one kind of knowledge resource that is rigorously associated to the ones' ability to read texts easily is vocabulary knowledge. Therefore, vocabulary is indispensable for reading comprehension. "In fact, without the recognition of the meaning of the words, it would be impossible to either produce or perceive the language" (Mehrpour, Razmjoo and Kian, 2011).

The remarkable role of vocabulary knowledge in reading comprehension has been well documented in first language (L1) studies and this has become visible to be the case in second language (L2) settings as well. Researchers have presented quite a lot of models to depict the relationship between vocabulary knowledge and reading comprehension.

\subsection{Vocabulary Knowledge and Reading Comprehension's Models}

As was pointed out earlier, the relationship between vocabulary knowledge and reading comprehension is multifaceted and active.

Anderson and Freebody (1981) offered a model for understanding and appreciating the strong relationship between vocabulary knowledge and comprehension through three hypotheses: a) the instrumentalist hypothesis, b) the aptitude hypothesis, and c) the knowledge hypothesis. The commonsense model of these three is the very instrumentalist hypothesis. According to this model what turns an ordinary reader into a better reader is learning more words; consequently, in order to enhance comprehension, vocabulary words should be taught and learned. Mezynski (1983) proposed a fourth "access" hypothesis. According to this hypothesis, vocabulary has a causal relationship with comprehension on condition that the vocabulary can be easily accessed.

Haynes (1993) also confirmed that nearly all major problems and handicaps for L2 readers is not lack of reading strategies but inadequate vocabulary in English.

Many studies have confirmed that vocabulary knowledge is one of the paramount predictors of reading capability and the means to obtain new information from texts (Nation, 2001; Qian, 2002; Read, 2000).

$\mathrm{Hu}$ and Nation (2000) argue that the following elements are involved in these models: a) background knowledge (sometimes called knowledge of the world), language knowledge (of which vocabulary knowledge is a part), skill in language use (of which reading comprehension is one result).

More recently, Grabe and Stroller (2001) have underlined the role of vocabulary knowledge in reading comprehension. In the same way, Stahl (2003) identify this relationship as a "robust" one and that vocabulary knowledge has constantly and consistently been the "foremost predictor of a text's difficulty" (p.241).

\section{Research on the relationship between vocabulary knowledge and reading comprehension}

Progressively, researchers have found that sufficient vocabulary knowledge is one of the vital elements of reading comprehension.

Early factor analytic studies believed that vocabulary knowledge is one of the key parts in reading comprehension (Davis, 1944; Spearritt, 1972). For instance, Davis (1944) analyzed tests of nine skills underlying reading comprehension and came to this result that the two most important skills in these tests were: a) vocabulary knowledge and b) reasoning. Spearritt (1972) reanalyzed Davis's (1944) records and finally asserted that the four major factors were: vocabulary knowledge, pursuing the organization of the 
passage, deducing the main points from the content and identifying the writer's purpose and intention. The most excellent distinguished element of these four skills was vocabulary knowledge.

Concerning the relationship between reading comprehension and vocabulary knowledge, Koda's (1989) conducted a study on 24 college students who were learning Japanese as a foreign language and found that a very strong link between vocabulary knowledge and reading comprehension.

Taking into account the effects of content knowledge and vocabulary knowledge on reading comprehension, Huang (1999) carefully calculated university students' vocabulary size and their reading comprehension ability. The subjects took Nation's (1990) Vocabulary Levels Test, a recall practice, an English passage and the Inventory of Content Knowledge and Interest Questionnaire. He found that university students' comprehension of any English passage depends on vocabulary knowledge and content knowledge, but their comprehension is completely bound for vocabulary knowledge.

Snow (2002) confirmed that the levels of power of relationship between a kindergarten vocabulary measure and reading comprehension amplified considerably at the same time as the children advanced in grade level. The correlations for first graders, fourth graders, and seventh graders were .45, .62, and .69, respectively. Gelderen et al. (2004) administered tests of English vocabulary knowledge and reading comprehension to 397 Dutch students from Grade 8 to Grade 10 in secondary education and found a correlation of 63 .

Guo (2006) scrutinized the relationship among vocabulary knowledge, reading comprehension and syntactic awareness of $155 \mathrm{English}$ speaking undergraduate and graduate students. Factor analysis shows that there is a very high correlation between syntactic awareness and reading comprehension. The results show that syntactic awareness directly influence reading comprehension, and indirectly influences reading comprehension via vocabulary knowledge.

\subsection{Vocabulary knowledge; Breadth and depth}

Researchers have discriminated between two aspects of vocabulary knowledge, that is depth and breadth (e.g. Bogaards and Laufer, 2004; Read, 2000). Nation (2001) declared that size or breadth of vocabulary knowledge is the number of words that language learners know.

Vocabulary breadth defines as the number of words a learner is familiar with at least on a surface. Vocabulary knowledge depth refers to the deepness of learner's repertoire of words (Qian and Schedl, 2004).

"Breadth of vocabulary knowledge is defined as the number of words that a person knows. With native speakers, the objective of studies in this area has been to measure the number of words that they know in some absolute sense, whereas with second language learners the aim is often more narrowly defined in terms of their knowledge of items in a specified list of relatively high frequency words, such as the General Service List". (Shen, 2008, p.136). Vocabulary Levels Test (VLT) which consists of various word-frequency levels varying from high frequency (2000-word level) to low-frequency words (10,000-word level) (Farvardin and Koosha, 2011).This well-known test has received great attentions and supports form several researchers and is now accepted by many researchers as a suitable measure of vocabulary breadth or size (e.g., Laufer \& Paribakht, 1998; Qian, 1999, 2002).

Alternatively, as Akbarian (2010) argues "depth of vocabulary knowledge refers to how well the language learner knows a word" (p. 392). Several researchers have attributed knowledge of spelling, collocational meanings, pronunciation, hyponymy, stylistic features, synonymy, and antonymy and etc to this kind of vocabulary knowledge (Nation, 1990; Read, 2000; Richards, 1976). Read (1993, 2000) developed Word Associates Test (WAT) to assess some of these aspects and it is nowadays accepted as the most well-known test for measuring depth of vocabulary knowledge of learners.

Ordonez et al $(2002$, p.719) regard breadth and depth as two vital aspects of vocabulary knowledge. They assert that "although lexical knowledge is most commonly thought of and assessed as a number of 
Vocabulary knowledge learning and reading comprehension performance: which one is superior - breadth or depth?

words known, or breadth of vocabulary, it is now increasingly clear that richness of the representation of the words known is also a key dimension of variability. We refer to this dimension as depth of vocabulary".

\subsection{The relationship between depth and breadth of vocabulary knowledge}

Schmitt and Meara (1997) investigated the relationship between depth and breadth of vocabulary knowledge and found that the correlations between word association and vocabulary size were strongly high. Therefore, it was rational to conclude that breadth and depth are two interrelated and vital dimensions of vocabulary knowledge.

After administering Vocabulary Levels Test (VLT) and the Word Associates Format, Qian (1999) came to a conclusion that the scores of the two tests were closely and significantly correlated.

Vermeer (2001) came to the conclusion that both breadth and depth of vocabulary are highly correlated. She concluded that "a deeper knowledge of words is the consequence of knowing more words, or that, conversely, the more words someone knows, the finer the networks and the deeper the word knowledge" (p.230). Vermeer (2001) concluded that there is no necessarily any conceptual distinction between the two dimensions (depth and breadth) of vocabulary.

Qian's (2002) investigation showed that depth of vocabulary knowledge is as important as that of vocabulary size in predicting academic reading performance.

\subsection{Research on the relationship between breadth and depth of vocabulary}

The relationship between both breadth and depth of vocabulary knowledge has been a focus of investigation among L1 reading researchers (Beck, Perfetti, and McKeown, 1982; Mezynski, 1983).

Laufer (1992) reported that the scores on reading comprehension correlated with both scores on the $\operatorname{VLT}(r=.50)$ and those on the EVST (Eurocentres Vocabulary Size Test) $(r=.75)$.

Read (1993), Nurweni and Read (in press) found a relatively high correlation between breadth and depth of vocabulary. Qian (1999) asserted that ESL learner's dimensions of breadth and depth of vocabulary knowledge are strongly associated.

Schmitt and Meara (1997) found that correlations between vocabulary breadth and WAT (as a depth test) were relatively high (.61 for receptive knowledge and .62 for productive knowledge). In another study, Nurweni and Read (1999) reported that the correlation between the scores on the tests of breadth and depth of vocabulary knowledge was .62 and the relationship became even stronger $(r=.81)$ with highproficiency students.

Later, Qian (2002) conducted a similar study with 217 participants from 19 different L1 backgrounds and reached the same conclusion.

\subsubsection{Relationship between reading comprehension and breadth and depth of vocabulary knowledge}

Regarding the importance of depth and breadth of vocabulary knowledge, few studies (Qian, 1999, 2002; Ouellette, 2006; Farahani, 2006) have investigated the relationship between depth and breadth of vocabulary knowledge and reading comprehension. Qian $(1999,2002)$ asserts that both breadth and depth of vocabulary knowledge play essential roles and that the polysemy, synonymy and collocation, which are vital elements in depth of vocabulary, are significant variables.

De Bot et al. (1997) confirmed that diverse aspects of vocabulary knowledge (breadth and depth) are strongly associated with reading comprehension processes. Qian (1999) assert that that breadth and depth of vocabulary knowledge and reading comprehension are greatly interrelated. Qian (1998; 1999; 
Seyed Mohammad Mohammadi y Nasrollah Bayat Afshar

$2000 ; 2002)$ has found that in reading comprehension, both depth and breadth of vocabulary knowledge play significant roles.

Typically, breadth of vocabulary knowledge in reading comprehension has been highlighted by several researchers (Liu and Nation, 1985). Laufer $(1996,1992)$, found high interrelations between vocabulary size and reading comprehension.Laufer (1996) and Qian's $(1999,2002,2004)$ research has produced results representing reasonably high correlation between breadth and depth of vocabulary knowledge and reading comprehension. Ouellette (2006) differentiated between breadth and depth of vocabulary knowledge in order to highlight the role of vocabulary in a variety of reading skills.

Tannenbaum (2006) investigated the relationships between three dimensions of word knowledge (breadth, depth and fluency) and reading comprehension. The results indicated that breadth and depth Ifluency present the best model to fit to the data. It was found that two aspects of word knowledge (depth and breadth) contribute a lot to the prediction of reading comprehension performance.

Likewise, Huang (2006) found that breadth and depth of vocabulary knowledge and reading comprehension are positively correlated.

\section{Studies conducted in Iran}

As far as the studies related to the topic of investigation conducted in Iran are concerned, one can refer to a few researches.

Rashidi and Khosravi (2010). tried to assess the role of depth and breadth of vocabulary knowledge in reading comprehension of Iranian EFL learners. They administered "all instruments (Word-Associate Test (WAT) (Read, 1993) measuring depth of vocabulary knowledge (DVK), Vocabulary Levels Test (VLT) (Nation, 1983) measuring Vocabulary Size (VS), and Reading Comprehension Test (RC)" together to 38 Iranian senior university students (Rashidi and Khosravi, 2010, p.81). Finally, they obtained the following results: a) the correlation among DVK, VS, and RC were very strong and positive; b) depth of vocabulary knowledge contributes a lot to the prediction and understanding of reading comprehension; and c) the stronger depth and breadth of vocabulary, the better performance on reading comprehension.

Farahani (2006) examined the relationship between depth of vocabulary knowledge and Iranian learners' lexical inferencing strategy. She concludes that that relationship between depth of vocabulary knowledge and lexical inferencing strategy type was highly significant.

Golkar and Yamini's study (2007) tried to empirically determine the reliability and validity of the passive and active versions of the Vocabulary Levels Tests. The participants were 76 Iranian undergraduate students majoring in engineering and English Language and Literature. Three tests of the Vocabulary Levels Test, the Productive Version of the Vocabulary Levels Test, and a TOEFL test were administered to students to find out the relationship between the two vocabulary tests and their relationship to their proficiency level and reading comprehension. The results proved the reliability and validity of Vocabulary Levels Tests as the tests of vocabulary size.

The learners' passive and active vocabularies were also highly correlated as a whole and at each separate word-frequency level. Passive vocabulary was always larger than active vocabulary at all levels. In addition, there was a high correlation between the learners' vocabulary knowledge on the one hand and proficiency and reading comprehension ability on the other hand.

In line with Nurweni and Read (1999), Akbarian (2010) found that VLT (breadth test) and WAT (depth test) had a great deal of common shared variance for Iranian ESP graduate students (R2=.746).

Kaivanpanah and Zandi (2009) attempted to investigate the role of depth of vocabulary knowledge in reading comprehension. A TOEFL test and a measure of depth of vocabulary knowledge were administered to $57 \mathrm{EFL}$ learners (17 males and 40 females). The analysis of the results showed that although depth of vocabulary knowledge is significantly related to reading, grammatical knowledge explains the greatest amount of variance in tests takers' performance on reading comprehension tests. 
Vocabulary knowledge learning and reading comprehension performance: which one is superior - breadth or depth?

\section{Conclusion}

Many researchers consider vocabulary learning as the most chief aspect of second-language (L2) learning (Knight, 1994; Schmitt, 2008, ). Vocabulary knowledge is essential for reading comprehension. As Stahl (1983, p.33) asserted, the relationship between reading comprehension and vocabulary knowledge is "one of the best documented relationships in reading research". Thus, many researchers suppose that a reader's vocabulary knowledge can be the best predictor of his understanding of text (Anderson \& Freebody, 1981).

There is a general agreement that vocabulary knowledge should be regarded as a multi-dimensional construct, therefore researchers no longer consider vocabulary knowledge having a single dimension.

The present study emphasizes that depth and breadth of vocabulary knowledge have a quite positive and significant correlations with each other and also with reading comprehension in English as a foreign language (EFL).

It also was found that while measures of size of vocabulary knowledge are strongly related to the reader's comprehension of text, measures examining aspects of depth of vocabulary knowledge make a stronger contribution to reading performance than those that simply measure a single definition of a word.

Therefore, both the vocabulary depth and size measures are valid in a predictive sense. As a result it is noteworthy to state that learners need to have a good knowledge of high frequency words along with adequate additional vocabulary to read.

\section{References}

Akbarian, I. (2010). The relationship between vocabulary size and depth for ESP/EAP learners. System, $38,391-401$.

Anderson, R.C. and Freebody, P. (1983). Reading comprehension and the assessment and acquisition of word knowledge. In Hutson, B., editor, Advances in reading/ language research: a research annual. Greenwich, CT: JAI Press, 231-56.

Anderson, R.C. and Freebody, P. (1981). Vocabulary knowledge. In Guthrie, J.T., editor, Comprehension and teaching: research reviews. Newark, DE: International Reading Association, 77-117.

Beck, I. L., McKeown, M. G., \& Kucan, L. (2002). Bringing words to life: Robust vocabulary instruction. New York: Guilford Press.

Beck, I. L., Perfetti, C. A., \& McKeown, M. G. (1982). The effects of long-term vocabulary instruction on lexical access and reading comprehension. Journal of Educational Psychology, 74, 506-521.

Bogaards, P., Laufer, B. (2004). Vocabulary in a Second Language. Amsterdam: John Benjamins Publishing Company.

Bromley, K. (2004). Rethinking vocabulary instruction. The Learning and Literacy Spectrum, 14, 3-12.

Chapelle, C. (1998). Construct definition and validity inquiry in SLA research. In L.F. Bachman, \& A.D. Cohen (Eds.), Interfaces between second language acquisition and language testing research (pp.32-70). Cambridge: Cambridge University Press.

Davis, F.B. (1944). Fundamental factors of comprehension in reading. Psychometrika, 9, 185-197.

De Bot, K., Paribakht, T. S., \& Wesche, M. B. (1997). Toward a lexical processing model for the study of second language vocabulary acquisition. Studies in Second Language Acquisition, 19, 309-329.

Farahani, F. (2006). The relationship between depth of vocabulary knowledge and EFL learners' lexical inferencing strategy use and success (Unpublished master's thesis). Shiraz Azad University. 
Seyed Mohammad Mohammadi y Nasrollah Bayat Afshar

Gelderen, A.V., Schoonen, R., Glooper, K.D., Hulstijn, J., Simis, A., Snellings, P., \& Steven, M. (2004). Linguistic knowledge, processing speed, and metacognitive knowledge in first and second language reading comprehension:A componential analysis. Journal of Educational Psychology, 1, 19-30.

Golkar, M., \& Yamini, M.(2007). Vocabulary and reading comprehension. The Reading Matrix, 7(3), 88112.

Grabe, W., \& Stoller, F.L. (2001): Teaching and researching reading. Harlow: Longman.

Guo,Y. (2006). The relationship among vocabulary knowledge, syntactic awareness and reading comprehension (Unpublished master's thesis). The Florida State University.

Haynes, M. (1993). Patterns and perils of guessing in second language reading. In T. Huckin, M. Haynes, \& J. Coady (Eds.), Second language reading and vocabulary (pp. 46-64). Norwood, NJ: Ablex.

Henriksen, B. (1999). Three dimensions of vocabulary development. Studies in Second Language Acquisition, 21, 303-317.

Hirsh, D., \& Nation, P. (1992). What vocabulary size is needed to read unsimplified texts for pleasure? Reading in a Foreign Language, 8, 689-696.

Hu, M., \& Nation, I. S. P. (2000). Vocabulary density and reading comprehension. Reading in a Foreign Language, 13(1), 403-430.

Huang, C. (1999). The effects of vocabulary knowledge and prior knowledge on reading comprehension of EFL students in Taiwan. Retrieved February 5, 2008, from http:// contentdm.lib.byu.edu/ETD/image/etd2508.pdf.

Huang, H. F. (2006). Breadth and Depth of Vocabulary Knowledge: Which Really Matters in the Academic Reading Performance of Chinese University Students? (Unpublished master's thesis). McGill University, Montreal, Canada.

Kaivanpanah, S., \& Zandi, H. (2009). The role of depth of vocabulary knowledge in reading comprehension in EFL context. Journal of Applied Sciences, 9(4), 698-706.

Knight, S. (1994). Dictionary: The tool of last resort in foreign language reading? A new perspective. The Modern Language Journal, 78, 285-299.

Koda, K. (1989). The effects of transferred vocabulary knowledge on the development of L2 reading proficiency. Foreign Language Annals, 22, 529-540.

Laufer, B. (1989). What percentage of text-lexis is essential for comprehension? In C. Lauren \& L. nordman (Eds.), Special language: From humans thinking to thinking machines (pp. 316-326). Clevedon, UK: multilingual Matters.

Laufer, B. (1992). How much lexis is necessary for reading comprehension? In P. Arnaud, \& H. Bejoint (Eds.), Vocabulary and applied linguistics, (pp. 126-132). London: Macmillan.

Laufer, B. (1996). The lexical threshold of second language reading comprehension: what it is and how it relates to L1 reading ability. In Saja-vaara, K. and Fairweather, C., editors, Approaches to second languageacquisition. Jyva"skyla": University of Jyva"skyla", 55-62.

Laufer, B. (1997). The lexical plight in second language reading: Words you don't know, words you think you know, and words you can't guess. In J. Coady. \& T. Huckin (Eds.), Second language vocabulary acquisition (pp. 20-34). Cambridge: Cambridge University Press.

Laufer, B., \& Paribakht. T. S. (1998). The relationship between passive and active vocabularies: Effects of language learning context. Language Learning, 48, 365- 391.

Liu, N., \& Nation, P. (1985). Factors affecting guessing vocabulary in Context. RELC Journal, 16, 33-42. 
Vocabulary knowledge learning and reading comprehension performance: which one is superior - breadth or depth?

Mezynski, K.(1983). Issues concerning the acquisition of knowledge: Effects of vocabulary training on reading comprehension. Review of Educational Research, 53, 253-279.

Nassaji, H. (2004). The relationship between depth of vocabulary knowledge and L2 learners,lexical inferencing strategy use and success. The Canadian Modern Language Review, 61(1), 107-134.

Nation, I. S. P. (1983). Testing and teaching vocabulary. Guidelines, 5, 12-25.

Nation, I. S. P. (1990). Teaching \& learning vocabulary. New York: Newbury House.

Nation,I. S. P. (2001). Learning vocabulary in another language. Cambridge: Cambridge University Press.

Nurweni, A. and Read, J. (1999). The English vocabulary knowledge of Indonesian university students. English for Specific Purposes 18, 161-75.

Nurweni, A., \& Read, J. (in press). The English vocabulary knowledge of Indonesian university students. English for Specific Purposes.

Ordonez, C. L., Carlo, M. S., Snow. C. E. \& Mclaughiin, B. (2002). Depth and breadth of vocabulary knowledge in two languages: Which vocabulary skills transfer? Journal of Educational Psychology, 94, 719-728.

Ouellette, G. P. (2006). What's meaning got to do with it: The role of vocabulary in word reading and reading comprehension. Journal of Educational Psychology, 98(3), 554- 566.

Qian, D.D. (1998). Depth of vocabulary knowledge: assessing its role in adults' reading comprehension in English as a second language (Unpublished doctoral thesis). University of Toronto.

Qian, D. (1999). Assessing the role of depth and breadth of vocabulary knowledge in reading comprehension. The Canadian modern language review, 56, 282-308.

Qian, D. (2002). Investigating the relationship between vocabulary knowledge and academic reading performance: an assessment perspective. Language Learning, 52, 513-36.

Qian, D., \& Schedl, M. (2004). Evaluation of an in-depth vocabulary knowledge measure for assessing reading performance. Language Testing. 21(1), 28-52.

Read, J. (1989). Towards a deeper assessment of vocabulary knowledge. Paper presented at the 8th World Congress of Applied Linguistics. Sydney, NSW, Australia.

Read, J. (1993). The development of a new measure of L2 vocabulary Knowledge. Language Testing, 10, 355-377.

Read, J. (1998). Validating a test to measure depth of vocabulary knowledge. In Kunnan, A., editor, Validation in language assessment. Mahwah, NJ:Lawrence Erlbaum, 41-60.

Read, J. (2000). Assessing vocabulary. Cambridge: Cambridge University Press.

Richards, J. C. (1976). The role of vocabulary learning. TESOL Quarterly, 10, 77-89.

Richek, M. (2005). Words are wonderful: Interactive, time-efficient strategies to teach meaning vocabulary. The Reading Teacher, 58(5), 414-423.

Schelling, G., Aarnoutse, C., \& Leeuwe, J. V. (2006). Third-grader's think-aloud protocols: Types of reading activities in reading an expository text. Learning and Instruction, 16(6), 549-568.

Schmitt, N., (2008). Review article: Instructed second language vocabulary learning. Language Teaching Research, 12, 329- 363.

Schmitt, N. \& Meara, P. (1997). Researching vocabulary through word knowledge framework: Word associations and verbal suffixes. Studies in Second Language Acquisition, 19, 17-36.

Snow, C. (2002). Oral language development and demographic change. Presentation at the Institute for Statewide Literacy Initiatives, Harvard Graduate School of Education, Cambridge, MA. 
Seyed Mohammad Mohammadi y Nasrollah Bayat Afshar

Spearritt, D. (1972). Identification of sub-skills of reading comprehension by maximum likelihood factor analysis. Reading Research Quarterly, 8, 92-111.

Stahl, S. (2003). Vocabulary and readability: How knowing word meanings affects comprehension. Topic in Language Disorder, 23(3), 241-247.

Tannenbaum, K. R. (2006). Relationships between word knowledge and reading comprehension in thirdgrade children. Scientific Studies of Reading, 10(4), 381- 398.

Vermeer, A., (2001). Breadth and depth of vocabulary in relation to L1/L2 acquisition and frequency of input. Applied Psycholinguistics, 22, 217- 234.

Rashidi, N. \& Khpsravi, N. (2010). Assessing the Role of Depth and Breadth of Vocabulary Knowledge in Reading Comprehension of Iranian EFL Learners. Pan-Pacific Association of Applied Linguistics 14(1), 81-108.

Mehrpour, S.Razmjoo, S. A. \& Kian, p. (2011).The Relationship between Depth and Breadth of Vocabulary Knowledge and Reading Comprehension among Iranian EFL Learners. Journal of English Language Teaching and Learning,53, 222.

Qian, D. D. \& Schedl, M.(2004). Evaluation of an in-depth vocabulary knowledge measure for assessing reading performance. Language Testing, 21 (1) 28-52.

Shen, Z. (2008). The Roles of Depth and Breadth of Vocabulary Knowledge in EFL Reading Performance. Asian Social Science, Vol. 4, No. 12.

Farvardin, M. T. \& Koosha, M. (2011). The Role of Vocabulary Knowledge in Iranian EFL Students' Reading Comprehension Performance: Breadth or Depth? Theory and Practice in Language Studies, Vol. 1, No. 11, pp. 1575-1580. 